\title{
THE ANTI-SUIT INJUNCTION AND THE EU: LEGAL TRADITION AND EUROPEANISATION IN INTERNATIONAL PRIVATE LAW
}

Neil A Dowers ${ }^{*}$

\section{Introduction}

The anti-suit injunction is a traditional international private law (IPL) remedy used by common law courts. This paper shall describe the use of the anti-suit injunction by courts in England, before setting out the approach taken by the Court of Justice of the European Union (Court of Justice) in two landmark cases to the use of anti-suit injunctions within Europe. This paper will ask whether the erosion of this IPL tradition through Europeanisation is to be regretted, concluding that, in this instance, tradition had to be abandoned in the name of progress.

\section{The traditional approach to the anti-suit injunction}

The anti-suit injunction is a court order rendered against a private party with the aim either of preventing that party raising an action in another forum, or forcing that party to discontinue such an action if already started. If the party disregards the anti-suit injunction and continues with the foreign action, it will face sanctions in the enjoining forum. The anti-suit injunction is a very powerful

\footnotetext{
LLB (Hons) (Glasgow), LLM (Cornell), candidate for PhD in Law and tutor at the University of Edinburgh. With thanks to my supervisor at Edinburgh, Dr Simone Lamont-Black, for her characteristically meticulous comments on a draft and for encouraging and helping me to consider this topic with an open mind. Thanks also to my friends Scott WD Macpherson and Amany Chamieh for proof reading in draft at extremely short notice. Any errors and opinions remain my own.
}

Copyright $\odot$ the Author(s).

This work is licensed under a Creative Commons Attribution-NonCommercial-NoDerivs 3.0 License. 
tool in preventing duplicative litigation, especially if the party has business, assets, or even attractive business prospects in the issuing forum. ${ }^{1}$

English courts draw their jurisdiction to render anti-suit injunctions from the general power to issue injunctions 'in all cases in which it appears to the court to be just and convenient to do so', enshrined in the Senior Courts Act 1981 (England and Wales). ${ }^{2}$ The exact extent of the power is ill-defined and has been the subject of a great many cases. ${ }^{3}$ For the purposes of this paper, the most important point to note is simply that the courts consider themselves to have jurisdiction to issue anti-suit injunctions, irrespective of the conditions under which they will exercise that jurisdiction.

The courts' struggle with the correct use of the anti-suit injunction is relevant for three main reasons. First, it helps to explain why the remedy is so controversial and demonstrates some of the reasons the Court of Justice would ultimately choose to ban its use within Europe. Second, it demonstrates that English courts were not 'trigger happy' with anti-suit injunctions, which they would only issue in fairly extreme circumstances. Finally, the case law demonstrates a difference in approach between those anti-suit injunctions that protect a contractual agreement to sue in a particular forum and those that do not, a difference that will remain relevant throughout this paper.

The anti-suit injunction is so controversial because it represents an indirect interference with the judicial processes of a foreign sovereign state, as courts in England ${ }^{4}$ and the USA ${ }^{5}$ have noted. English authority suggests that the courts consider the order to be addressed solely to a party over whom the English court enjoys in personam jurisdiction ${ }^{6}$ and not to the foreign court, and therefore any interference with the foreign judicial process is not unconscionable. This reasoning has come under much criticism and has been dubbed the 'English

${ }^{1} \mathrm{~J} J$ Barceló III, 'Anti-Foreign-Suit Injunctions to Enforce Arbitration Agreements' in A Rovine (ed), Contemporary Issues in International Arbitration and Mediation (2007) 107, 108.

2 Senior Courts Act 1981 (England and Wales) s 37 (1). South Carolina Insurance Co v Assurantie Maatschappij 'De Zeven Provincien' NV [1987] AC 24 (HL), 39 (Lord Brandon).

3 See S Gee, Commercial Injunctions ( $5^{\text {th }}$ edn, 2004), ch 14.

4 Turner v Grovit [2001] UKHL 65, [2002] 1 WLR 107, para 28 (Lord Hobhouse); Airbus Industrie GIE v Patel and Others [1999] 1 AC 119 (HL), paras 131-2 (Lord Goff).

5 The US Supreme Court acknowledged over 150 years ago that in practical terms an anti-suit injunction is a direct interference in the judicial proceedings of an independent forum. Peck $v$ Jenness 48 US (7 How) 625 (1949). For a more recent expression of that opinion, citing Peck, see: Laker Airways Ltd v Pan American Airways 559 F Supp 1124 at 1128 (DC Cir, 1983).

6 Turnerv Grovit, above n 4, para 23 (Lord Hobhouse); Donohue v Armco Inc and others [2001] UKHL 64, [2002] 1 Lloyd's LR 425, para 19 (Lord Bingham). 
artifice.7 Even the House of Lords' own case law is inconsistent in its application of this theory, with Lord Goff having explicitly acknowledged in Airbus Industrie that 'this part of the law is concerned with the resolution of clashes between jurisdictions. ${ }^{8}$ The controversy within Europe is compounded by a clash of legal traditions: only common law courts will issue anti-suit injunctions, while the civil law tradition views the remedy as offensive against sovereignty and international law. ${ }^{9}$ Furthermore, the grant of anti-suit injunctions is self-evidently offensive to the principles of international comity. ${ }^{10}$

The English courts therefore faced something of a minefield in delineating when exactly it would be appropriate to issue an anti-suit injunction. Ultimately, the court would distinguish between two categories of cases: those in which the court was asked for an anti-suit injunction to enforce an agreement to sue in a particular forum-sometimes also expressed negatively as a contractual right not to be sued in another forum-and all other cases.

In the former category of cases, where proceedings are brought in a forum other than that contractually agreed between the parties, there will be a presumption in favour of issuing the anti-suit injunction unless the opposing party can demonstrate compelling reasons why the court should not do so. ${ }^{11}$ This is true whether the agreement gives jurisdiction to a court ${ }^{12}$ or an arbitral tribunal. ${ }^{13}$ These circumstances provide 'the paradigm case for the prompt issue of an injunction ${ }^{14}$ with 'no good reason for diffidence.'15

In all other cases, 'diffidence' might very well be considered the byword.

${ }^{7}$ C Ambrose, 'Can Anti-Suit Injunctions Survive European Community Law?' (2003) 52 ICLQ 401, 404-10.

${ }^{8}$ Airbus Industrie, above n 4, para 131 (Lord Goff).

9 Re the Enforcement of An English Anti-Suit Injunction Case 3VA 11/95 Oberlandesgericht (Regional Court of Appeal) Düsseldorf 10 January 1996, [1997] ILPr 320, paras 5, 12; J Harris, 'Restraint of Foreign Proceedings-The View from the Other Side of the Fence' (1997) CJQ 283; Barceló, above $\mathrm{n} 1,4$.

${ }^{10}$ Ibid. See also R Fentiman, 'Anti-Suit Injunctions-Comity Redux?' (2012) 71 CLJ 273; T Kruger, 'The Anti-Suit Injunction in the European Judicial Space: Turner v Grovit' (2004) 53 ICLQ 1030, 1033.

${ }^{11}$ Donohue, above n 6, paras 24 (Lord Bingham) and 45 (Lord Woodborough). See also Gee, above n 3, 401-2.

${ }^{12}$ National Westminster Bank plc v Utrecht-America Finance Co [2001] EWCA 658, [2001] CLC 1372, para 1384 (Clarke LJ).

${ }^{13}$ Aggeliki Charis Compania Maritima SA v Pagnan SpA [1995] 1 Lloyd's LR 87 (CA), paras 94-7 (Leggatt LJ, Millett LJ and Neill LJ) (The Angelic Grace).

${ }^{14}$ Ibid, para 94 (Leggatt LJ).

${ }^{15}$ Ibid, para 96 (Millett LJ). 
Caution is necessary for the same reasons outlined above as to why the anti-suit injunction is a controversial remedy, especially the interference with judicial proceedings in a foreign sovereign state. ${ }^{16}$ In deciding whether to grant an injunction, the court will not apply rigid principles, ${ }^{17}$ but will consider whether the party against whom the injunction is sought has acted unfairly in pursuing its action in the foreign forum. ${ }^{18}$ This might include, for example, where the foreign action is vexatious or oppressive. ${ }^{19}$ It will consider which is the more appropriate forum for resolution of the dispute, ${ }^{20}$ but will not issue an injunction solely on the basis of this so-called forum non conveniens doctrine. ${ }^{21}$ The court will also consider whether an anti-suit injunction is required to protect a sufficiently important public policy interest, ${ }^{22}$ and whether there is any specific reason that the foreign proceedings should be allowed to continue. Such reasons could include, for example, the availability of any remedy in the foreign forum not available in England, ${ }^{23}$ or the fact that the foreign proceedings are at an advanced stage. ${ }^{24}$ Finally, the court will consider whether the target of the injunction is amenable to the jurisdiction of the court and therefore whether the injunction will provide an effective remedy. ${ }^{25}$ In summary, the court will consider numerous factors, with the overarching proviso that it should exercise its power to issue anti-suit injunctions cautiously due to comity and policy considerations.

The dichotomous approach can be explained as follows. The court recognises the possibility for dispute ${ }^{26}$ as to the appropriate forum absent contractual agreement, and 'cannot arrogate itself the power to resolve that dispute by granting an injunction'; ${ }^{27}$ a possibility it does not see where the parties have made

${ }^{16}$ De Zeven Provincien, above n 2, para 40 (Lord Brandon); Donohue, above n 6, para 19 (Lord Bingham); National Westminster Bank, above n 12, 1382 (Clarke LJ).

17 Gee, above n 3, 398.

${ }^{18}$ British Airways Board and others v Laker Airways Ltd [1985] AC 58 (HL), para 81 (Lord Diplock).

${ }_{19}$ Airbus Industrie, above n 4, para 133 (Lord Goff).

${ }^{20}$ Ibid.

${ }^{21}$ EI Du Pont de Nemours \& Company and Endo Laboratories Inc v Agnew [1988] 2 Lloyd's LR 240 (CA), para 23 (Dillon LJ).

${ }^{22}$ Gee, above n 3, 399.

${ }^{23}$ Société Nationale Industrielle Aerospatiale v Lee Kui Jak and another [1987] AC 871 (HL), para 896 (Lord Goff).

${ }^{24}$ Ibid, para 880 (Lord Goff).

${ }^{25}$ Donohue, above n 6, para 19 (Lord Bingham).

${ }^{26}$ This refers to the possibility for dispute between itself and another court and not dispute between the parties.

${ }^{27}$ National Westminster Bank, above n 12, para 28 (Lord Clarke). 
an agreement conferring jurisdiction. ${ }^{28}$

The stage is set, then, with the English courts willing and able to issue anti-suit injunctions, readily where there is an agreement conferring jurisdiction, hesitantly otherwise. By contrast, most other member states of the European Union view the anti-suit injunction as offensive to sovereignty. Enter the Court of Justice.

\section{The Brussels Regime and the Court of Justice approach}

The Court of Justice considered the anti-suit injunction in two contexts in two leading cases: Turner ${ }^{29}$ and West Tankers. ${ }^{30}$ Before considering these judgments, it is necessary to describe briefly the legal climate in which they were handed down.

The first important point to note is the existence of the Brussels Regime. The Brussels Regime is a collective term for a set of instruments allocating jurisdiction between European Union member states in civil and commercial matters. ${ }^{31}$ The relevant instruments to this part of this discussion are the Brussels Convention of $1968^{32}$ and the Brussels I Regulation. ${ }^{33}$ One of the principal goals of the Brussels Regime is to resolve conflicts of jurisdiction between member states, ${ }^{34}$ which is also one of the reasons that the English courts issue anti-suit injunctions. ${ }^{35}$

The second important factor to note is the development of the normative concept of 'mutual trust' between member states. Mutual trust is mentioned as a foundational principle of the Brussels I Regulation, ${ }^{36}$ though not of the Brussels

\footnotetext{
${ }^{28}$ The Angelic Grace, above n 13, para 96 (Lord Millett).

${ }^{29}$ Case C-159/02, Gregory Paul Turner v Felix Fareed Ismail Grovit and others [2004] ECR I-3565.

${ }^{30}$ Case C-185/07, Allianz SpA (formerly Riunione Adriatica di Sicurtà SpA) and Generali Assicurazioni Generali SpA v West Tankers Inc [2009] ECR I-663.

${ }^{31}$ Here used in the sense of both direct jurisdiction and indirect jurisdiction (i.e. recognition and enforcement). For discussion of these terms, see R Michaels, 'Some Fundamental Jurisdictional Conceptions as Applied in Judgment Conventions' in E Gottschalk, R Michaels, G Ruhl \& J von Hein (eds), Conflict of Laws in a Globalizing World (2006) 29.

${ }^{32}$ Convention on Jurisdiction and the Enforcement of Judgments in Civil and Commercial Matters, 27 September 1968, 1262 UNTS 153 (Brussels Convention).

${ }^{33}$ Council Regulation (EC) No 44/2001 of 22 December 2000 on Jurisdiction and the Recognition and Enforcement of Judgments in Civil and Commercial Matters [2000] OJ L 12/1 (Brussels I Regulation).

${ }^{34}$ Brussels Convention, above n 32, Preamble.

${ }^{35}$ Airbus Industrie, above n 4, para 131 (Lord Goff).

${ }^{36}$ Brussels I Regulation, above n 33, Recitals 3 and 16.
} 
Convention. In the IPL context, mutual trust has at its heart the notion that courts of one member state should respect the right of the court of another member state to determine its own jurisdiction and respect the result it reaches. The concept clearly underlies the judgment in the Overseas Union case, ${ }^{37}$ albeit not expressly mentioned, and was a central part of the ratio decidendi in the Gasser case, ${ }^{38}$ decided under the Brussels Convention one year before Turner. Mutual trust has also been argued to be a wide-ranging, long-standing tenet of European law, specifically visible in case law concerning fundamental freedoms. ${ }^{39}$

It was in this context that the Turner case came before the Court of Justice. The facts, in relevant part, are as follows. Turner, a British national, began proceedings for unfair dismissal against his Spanish employer before the Employment Tribunal in London in May 1997. In July 1998, the employer began an action against Turner for a large sum of damages in respect of breach of contract before a Madrid first instance court. Turner sought an anti-suit injunction against these proceedings, which was granted on the basis that the Spanish proceedings were brought in bad faith and with the intent of obstructing the ongoing English proceedings. ${ }^{40}$ The injunction was then appealed via the Court of Appeal ${ }^{41}$ all the way to the House of Lords, which was obliged to make a preliminary reference to the Court of Justice. ${ }^{42}$

The question referred to the Court of Justice was:

Is it inconsistent with the [Brussels Convention] (subsequently acceded to by the United Kingdom) for the courts of the United Kingdom to grant restraining orders against defendants who are threatening to commence or continue legal proceedings in another Convention country when those defendants are acting in bad faith with the intent and purpose of frustrating or obstructing proceedings properly before the English courts? ${ }^{43}$

\footnotetext{
${ }^{37}$ Case C-351/89, Overseas Union Insurance Ltd and others v New Hampshire Insurance Company [1991] ECR I-03317.

${ }^{38}$ Case C-116/02, Erich Gasser GmbH v MISAT Srl [2003] ECR I-14693, para 72.

${ }^{39}$ See generally F Blobel \& P Spath, 'The Tale of Multilateral Trust and the European Law of Civil Procedure' (2005) ELR 528, 533; National Westminster Bank, above n 12, para 28 (Lord Clarke); The Angelic Grace, above n 13, para 96 (Lord Millett). The authors argue that mutual trust is an important element in the decision of the landmark Cassis de Dijon case: Case C-120/78, Rewe-Zentrale AGv Bundesmonopolverwaltung für Branntwein [1979] ECR I-00649.

${ }^{40}$ Turner $v$ Grovit [1999] 1 All ER (Comm) 445.

${ }^{41}$ Turner $v$ Grovit [2000] QB 345.

42 Turner v Grovit, above $\mathrm{n} 4$.

${ }^{43}$ Ibid, para 21 (Lord Hobhouse).
} 
Note that the proceedings were already underway before the courts of England, which had accepted jurisdiction under the Brussels Convention. This would mean that under Article 21 of the Brussels Convention the Spanish courts would have to stay or dismiss proceedings, being the court second-seised of the same dispute. Note also that the injunction issued was not enforcing a contractual right of Turner not to be sued in Spain. It was therefore the kind of injunction the English courts hesitate to issue.

The House of Lords relied on this hesitancy in arguing in favour of the antisuit injunction in its preliminary reference. ${ }^{44}$ Other arguments raised included the rather weak contention that issuing an anti-suit injunction does not entail interference with the jurisdiction of the foreign court, discussed above. ${ }^{45}$ Finally, it was argued that the anti-suit injunction should be considered compatible with the Brussels Convention as it furthers a legitimate aim of the Convention by providing an effective mechanism to prevent parallel proceedings. ${ }^{46}$ The prevention of parallel proceedings was clearly a goal of the Convention, ${ }^{47}$ and would later be expressly enshrined in a recital to the Brussels I Regulation. ${ }^{48}$ The House of Lords therefore reasoned that, because it achieves a goal of the Convention in a way not expressly prohibited by the Convention, use of the anti-suit injunction should be permitted within Europe.

The crux of the argument against the anti-suit injunction's compatibility with the Convention was based on the doctrine of mutual trust. The anti-suit injunction, it was argued, casts doubt on 'the reciprocal trust established between the various national legal systems' ${ }^{49}$ Advocate General Ruiz-Jarabo Colomer believed this fact should be decisive, as the Convention represented an important landmark in European judicial co-operation, which is imbued with the concept of mutual trust, which presupposes that each State recognises the capacity of other legal systems to contribute independently, but harmoniously, to attainment of the stated objectives of integration. ${ }^{50}$

The Court of Justice agreed, placing the principle of mutual trust paramount in its judgment. ${ }^{51}$ The Court deals easily with the UK's arguments in favour

\footnotetext{
${ }^{44}$ Ibid, paras 24-7 (Lord Hobhouse).

${ }^{45}$ Ibid, paras 22-3 (Lord Hobhouse). See also discussion above n 7-11.

${ }^{46}$ Ibid, para 36 (Lord Hobhouse).

${ }^{47}$ See Brussels Convention, above n 32, Arts 21, 27 (3).

${ }^{48}$ Brussels I Regulation, above n 33, Recital 15.

${ }^{49}$ Case C-159/02, Gregory Paul Turner v Felix Fareed Ismail Grovit and others [2004] ECR I-3565, Opinion of Advocate General Ruiz-Jarabo Colomer, para 30.

${ }^{50}$ Ibid, para 31.

${ }^{51}$ Ibid, paras $24-5$.
} 
of the anti-suit injunction, reasoning that the Convention deliberately does not permit one court to review the jurisdiction of another ${ }^{52}$ and that an anti-suit injunction 'must be seen as interfering with the jurisdiction of the foreign court. ${ }^{\text {. }}$. The anti-suit injunction is, therefore, incompatible with the Convention and the principle of mutual trust, no matter how sparingly, or under what circumstances, it is utilised.

The UK's argument that the anti-suit injunction achieves stated goals of the Convention was also rejected. The Court points out that the use of anti-suit injunctions leaves no room for the operation of the Article 21 lis pendens rule, which could otherwise have been invoked by Turner to compel the Madrid court to stay proceedings. ${ }^{54}$ It also raises concerns that allowing the use of anti-suit injunctions would create new conflicts, not contemplated or regulated by the Convention. $^{55}$

The Court of Justice in Turner effectively banned the use of anti-suit injunctions in situations where the Brussels Convention allocates jurisdiction. Applying the doctrine of mutual trust, the court first-seised which has accepted jurisdiction must allow a court second-seised to determine its own jurisdiction under the Convention, which would mean staying proceedings or declining jurisdiction under the lis pendens rule. English courts would thus no longer be able to issue anti-suit injunctions against proceedings in another member state to protect litigants where the English court has jurisdiction under the Convention, which would include cases where the English court is designated in an exclusive choice of court agreement. ${ }^{56}$

The decision was greeted with disappointment, if not surprise, by English commentators. ${ }^{57}$ That the Court of Justice would not look favourably on perceived interference with the Brussels Convention's allocation of jurisdiction could hardly come as a shock. What, though, of cases where the Convention does not allocate jurisdiction?

This question would come before the Court of Justice in the West Tankers case. ${ }^{58}$ The relevant facts are as follows. A ship owned by West Tankers and

\footnotetext{
52 Ibid, para 26.

53 Ibid, para 27.

${ }^{54}$ Ibid, para 30.

55 Ibid.

${ }^{56}$ Jurisdiction under a choice of court agreement is governed by the Brussels Convention, Art 17.

${ }^{57}$ See e.g. A Briggs, 'Anti-suit injunctions and Utopian ideals' (2004) 120 LQR 529; C Hare, 'A lack of restraint in Europe' (2004) 63 CLJ 570.

${ }^{58}$ West Tankers, above n 30.
} 
chartered by an Italian party collided with and damaged a dock owned by the latter in Syracuse, Italy. The charterparty contained a clause for arbitration of disputes in London. The Italian party was indemnified by its Italian insurers up to the limit of its policy, and recovered the balance of damages in London arbitration without incident. The insurers then began a subrogated action before the Italian courts in Syracuse to recover from West Tankers the sum paid out under the insurance policy. The action before the court was in tort and, but for the potentially effective arbitration clause, the Italian courts would have had jurisdiction under the Brussels I Regulation, ${ }^{59}$ which had by then largely superseded the Brussels Convention. ${ }^{60}$ West Tankers applied to the English courts for an anti-suit injunction restraining any proceedings by the insurer other than London arbitration, which was granted because under English law a party pursuing a subrogated right is also subrogated into an arbitration clause binding on the original parties to the dispute. ${ }^{61}$ The same is not necessarily true in Italian law, and although the New York Convention points to the law of the seat of the arbitration (in this case English law) as the appropriate law to resolve this question, ${ }^{62}$ it is unclear what result the Italian court might have reached as to its own jurisdiction. The insurer appealed the anti-suit injunction to the House of Lords, which made a preliminary reference to the Court of Justice on the question:

Is it consistent with EC Regulation 44/2001 for a court of a Member State to make an order to restrain a person from commencing or continuing proceedings in another Member State on the ground that such proceedings are in breach of an arbitration agreement? ${ }^{63}$

The facts of this case differ from those in Turner because the Brussels I Regulation does not allocate jurisdiction where arbitration is concerned. In fact, the Brussels I Regulation expressly excludes arbitration from its scope, as had the Brussels

\footnotetext{
${ }^{59}$ Brussels I Regulation, above n 33, Art 5 (3).

${ }^{60}$ There is continuity between the Brussels Convention and the Brussels I Regulation, per Recital 19 of the Regulation, and jurisprudence of the former is applicable to the latter where relevant. See e.g. the Court of Justice's references in the West Tankers judgment, above n 30, para 28, to several Brussels Convention cases.

${ }^{61}$ West Tankers Inc v Ras Riunione Adriatica di Sicurta SpA [2005] EWHC 454 (Comm).

${ }^{62}$ Convention on the Recognition and Enforcement of Foreign Arbitral Awards, 10 June 1958, 330 UNTS 3, Art V (1) (a) (New York Convention).

${ }^{63}$ West Tankers Inc v Ras Riunione Adriatica di Sicurta SpA and Others [2007] 1 All ER (Comm) 794, para 23 (Lord Hoffmann) (West Tankers (HL)).
} 
Convention. ${ }^{64}$ The Court of Justice had already held in the Marc Rich case that the existence of an action on the merits in another member state should not interfere with court proceedings in support of arbitration. ${ }^{65}$ Furthermore, since The Angelic Grace, ${ }^{66}$ the English courts had readily issued anti-suit injunctions in support of arbitration, and commentators, including some eminent civilian scholars, have argued that the protection of an arbitration agreement is a situation in which issuing an anti-suit injunction could be considered justifiable. ${ }^{67}$ Finally, it should be noted that London is one of the few truly thriving international arbitration hubs in Europe, and it was feared that any interference with England's arbitration process might harm London's arbitration practice. ${ }^{68}$ In the totality of the circumstances, and especially because of the exclusion of arbitration from the Brussels I Regulation, it was entirely conceivable that the Court of Justice might reach a different conclusion on the anti-suit injunction in West Tankers than in Turner.

Ultimately, however, the court reached the same conclusion: the anti-suit injunction could not be used, even in these circumstances, to restrain proceedings in another member state. In a judgment that focused more on broad policy than technical legal arguments, the Court of Justice ruled that, because the Italian courts would have had jurisdiction over the substantive dispute under the Brussels I Regulation but for the arbitration clause, the English courts could not interfere in its decision whether or not to exercise that jurisdiction; to do so would be to interfere with the effectiveness of the Regulation. ${ }^{69}$ This is true even though the Brussels I Regulation does not provide a set of rules allocating jurisdiction where an arbitration agreement is concerned and the English proceedings in support of arbitration are expressly excluded from the Regulation's scope. The English courts must allow the Italian proceedings to run their course, and the Italian court to determine whether it will accept jurisdiction under the Regulation or refuse it under Article II (3) of the New York Convention. ${ }^{70}$ The mutual trust

\footnotetext{
${ }^{64}$ Brussels I Regulation, above n 33, Art 1 (2) (d); Brussels Convention, above n 32, Art 1 (4).

${ }^{65}$ Case C-190/89, Marc Rich \& Co AG v Società Italiana Impianti PA [1991] ECR I-3855, paras 26-9.

${ }^{66}$ The Angelic Grace, above n 13.

${ }^{67}$ B Hess, T Pfeiffer \& P Schlosser, Report on the Application of Regulation Brussels I in the Member states [2007] Study JLS/C4/2005/03, para 123 (Heidelberg Report); Barceló, above n 1, 2.

${ }^{68}$ A Trukhtanov, 'Anti-suit injunctions in support of arbitration-is the ECJ about to take away the English court's powers?' (2007) 10 Int ALR 136; B Steinbruck, 'The impact of EU law on anti-suit injunctions in aid of English arbitration proceedings' (2007) 26 CJQ 358. See also West Tankers (HL), above n 63, paras 17-21 (Lord Hoffmann).

${ }^{69}$ West Tankers, above n 30, paras 24, 28-30.

${ }^{70}$ Ibid, paras 28, 33.
} 
between the courts of the member states requires this result. ${ }^{71}$

And so it was that the Court of Justice finally prohibited the use of the antisuit injunction by English courts against proceedings in other European member states, stripping the courts of their traditional remedy in IPL. The decision was met with dismay by English commentators who feared that London might suffer as an arbitration venue, but there was little they could do beyond grinding their teeth and looking towards a new future without anti-European-suit injunctions. $^{72}$

\section{A new legal tradition}

It is clear that the Court of Justice's rulings on the anti-suit injunction have substantially limited access to a long-standing and important and valuable weapon' of the English courts in IPL. ${ }^{73}$ The English courts have long viewed themselves as having the prerogative to issue an anti-suit injunction, to the extent that the order has become a part of English, and indeed common-law, legal tradition. ${ }^{74}$ This tradition has clearly been eroded by the Europeanisation of IPL and the intervention of the Court of Justice.

However, it is important to consider what has come in the anti-suit injunction's place and not to criticise change for criticism's sake. The Court of Justice's rulings in the anti-suit injunction cases, together with its rulings in other IPL cases, have begun to usher in a new paradigm and perhaps the beginnings of a new tradition in European IPL: a tradition of mutual trust. ${ }^{75}$ The emergence of

\footnotetext{
${ }^{71}$ Ibid, para 30.

${ }^{72}$ See S Dutson \& M Howarth, 'After West Tankers-the rise of the 'foreign torpedo'?' (2009) 75 Arbitration 334; S Camilleri, 'The Front Comor-the end of arbitration as we know it?' (2010) 6 CSLR 214; J Tumbridge, 'European anti-suit injunctions in favour of arbitration agreements-a sea change?' (2010) 21 ICCLR 177; H Seriki, 'Anti-suit injunctions, arbitration and the ECJ: an approach too far?' (2010) 1 JBL 24; Y Baatz \& A Sandiforth, 'A setback for arbitration' (2009) STL 1; J Chuah., 'Serious blow to international commercial arbitration: The Front Comor' (2009) 57 SLR, 53. See also: A Dickinson, 'Dickinson on West Tankers: Another One Bites the Dust', Conflict of Laws Blog, 11 February 2009, <http://conflictoflaws.net/2009/dickinsonon-west-tankers-another-one-bites-the-dust/> [accessed 11 February 2013]; J Harris, 'Harris on West Tankers', Conflict of Laws Blog, 12 February 2009, <http://conflictoflaws.net/2009/harrison-west-tankers/> [accessed 11 February 2013].

${ }^{73}$ Pena Copper Mines Ltd v Rio Tinto Co Ltd [1911-13] All ER 209 (CA); West Tankers (HL), above n 63, para 19 (Lord Hoffmann).

${ }_{74}^{74}$ Barceló, above n 1, 2.

${ }^{75}$ See Overseas Union, above n 37; Case C-533/08, TNT Express Nederland BV v Axa Versicherung AG [2010] ECR I-04107, paras 49, 54-6; Case C-139/10, Prism Investments BV v van der Meer [2011]
} 
a trust-based system, in which courts in different European member states cooperate and respect one another's ability to decide and decisions rendered, has been recognised in scholarship. ${ }^{76}$ This is a move from legal imperialism to legal communitarianism; from unilateralism to multilateralism. It is a new way of approaching cases of lis pendens more in line with IPL in an internationalised form, such as the Brussels I Regulation or the proposed worldwide equivalent Hague Convention. This new approach is better suited to our increasingly globalised world.

But how well does this new approach work? At least in theory, where the Brussels I Regulation allocates jurisdiction, the mutual-trust-based approach should work well. In a situation such as in Turner, where the English court is the first-seised of an action and takes jurisdiction, any court subsequently seised should of its own motion decline jurisdiction under the lis pendens rule. ${ }^{77}$ Note that this is at any rate a situation in which the English courts would have been hesitant to issue anti-suit injunctions, so it will only be in a tiny minority of cases that a litigant who would otherwise have applied successfully for an injunction must now put his faith in the judgement of the foreign rather than the English court. The situation is different where the English court is second-seised of the same action, in which case it will have to stay proceedings pending the decision of the foreign court and will no longer be able to wrest control over a dispute by way of injunction. The exception to this is where the Brussels I Regulation provides for the exclusive jurisdiction of the courts of one member state, in which case the court having exclusive jurisdiction will be allowed to proceed regardless. ${ }^{78}$

The English courts were always more ready to issue an anti-suit injunction to protect a choice of court agreement. ${ }^{79}$ Under the ruling in Gasser, the jurisdiction of courts under these agreements was not protected in the same way as exclusive jurisdiction under Article 22 of the Brussels I Regulation, but

ECR I-09511, paras 27, 31; Case C-619/10, Trade Agency Ltd. v Seramico Investments Ltd [2012] OJ C 72/25; Case C-514/10, Wolf Naturprodukte GmbH v SEWAR spol Sro [2012] OJ C 13/37, para 25.

${ }^{76}$ See J Mance, 'Exclusive jurisdiction agreements and European ideals' (2004) 120 LQR 357, passim; E B Crawford, 'The uses of putativity and negativity in the conflict of laws' (2005) 54 ICLQ 829, 838; F Blobel \& P Spath, above n 39, passim; L Merrett, 'The enforcement of jurisdiction agreements within the Brussels regime' (2006) 55 ICLQ 315, 329; L Demeyere, 'Commercial litigating in the European Union: a changing landscape' (2008) 4 IBLJ 481, passim; P Shine, 'A matter of trust' (2009) 159 NLJ 1093; A Mourre \& A Vagenheim, 'The arbitration exclusion in Regulation 44/2001 after West Tankers' (2009) 12 Int ALR 75, 78.

${ }^{77}$ Brussels I Regulation, above n 33, Art 27.

${ }^{78}$ Ibid, Art 22; Overseas Union, above n 37, para 26.

${ }^{79}$ See National Westminster Bank, above n 12. 
was subject to the ordinary lis pendens rule at Article $27^{80}$ In the Brussels I Regulation Recast, which will take effect on 10 January $2015,{ }^{81}$ this rule has been reversed, meaning that proceedings before a court designated in a choice of court agreement will be able to proceed regardless of whether that court was first- or second-seised of the action. ${ }^{82}$ The courts of other member states will be required to stay once the designated court has been seised. ${ }^{83}$ This should support party autonomy and enhance the effectiveness of choice of court agreements in a far less divisive fashion than the unilateral injunction of proceedings before one court by another. ${ }^{84}$ The prohibition of the anti-suit injunction should thus cause little-to-no harm in situations where the Brussels Regime allocates jurisdiction.

The same cannot be said for situations in which the Brussels I Regulation does not allocate jurisdiction, namely, where the anti-suit injunction would have been issued to protect an arbitration agreement. In this case, it is Article II (3) of the New York Convention that allocates jurisdiction to the arbitral tribunal rather than any rule of the Brussels I Regulation. Indeed, because of the exclusion of arbitration at Article 1(2) (d) of the Brussels I Regulation and the combined case law of Marc Rich ${ }^{85}$ and West Tankers, ${ }^{86}$ there is effectively a right to commence parallel court proceedings alongside arbitration. The only thing preventing the parallel arbitration and litigation of the entire dispute is the hope for harmonious application of the New York Convention, which is not subject to oversight and enforcement by a supranational body like the Court of Justice. This is so despite arguments from commentators that the enforcement of an arbitration agreement should be considered a special case, ${ }^{87}$ calls for reform to protect arbitration agreements in the Heidelberg Report, ${ }^{88}$ and a proffered solution in the Commission's Green Paper ${ }^{89}$ and Recast proposal, ${ }^{90}$ ultimately rejected by the

\footnotetext{
${ }^{80}$ Gasser, above n 38, paras 42-54.

${ }^{81}$ Regulation (EU) No 1215/2012 of the European Parliament and of the Council of 12 December 2012 on jurisdiction and the recognition and enforcement of judgments in civil and commercial matters (recast) [2012] OJ L 351/1, Art 81 (Brussels I Regulation Recast).

${ }^{82}$ Ibid, Recital 22, Art 31.

${ }^{83}$ Ibid.

${ }^{84}$ N A Dowers \& D Holloway, 'Brussels I Recast passed' (2013) 16 Int ALR N18, N21.

${ }^{85}$ Marc Rich, above n 65.

${ }^{86}$ West Tankers, above $\mathrm{n} 30$.

${ }^{87}$ Barceló, above n 1, 2; Ambrose, above n 7, 419.

${ }^{88}$ Heidelberg Report, above n 67, para 123.

${ }^{89}$ European Commission Green paper on the review of Council Regulation (EC) No 44/2001 on jurisdiction and the recognition and enforcement of judgments in civil and commercial matters, COM (2009) 175 final, s 6.

${ }^{90}$ European Commission Proposal for a Regulation of the European Parliament and of the Council on
} 
European Parliament ${ }^{91}$ and discarded as the legislature pursued other legislative priorities. $^{92}$ Instead of this, the Recast adds a recital ${ }^{93}$ reaffirming the arbitration exclusion in an unclear fashion likely to cause as many problems as it solves. ${ }^{94}$ It is also inconsistent with the autonomy-based approach to choice of court agreements taken in the Brussels I Recast. ${ }^{95}$ The English courts are therefore quite likely to find themselves in a position where they wish they still had access to anti-suit injunctions to protect arbitration agreements. Nonetheless, this is a problem that could and should be solved by a rethinking of the Brussels I Regulation's relationship with arbitration ${ }^{96}$ and not by the regressive step of re-instating the anti-suit injunction.

\section{Conclusion}

The replacement of the English tradition of issuing anti-suit injunctions as an IPL remedy by a European tradition of mutual trust in the administration of justice by courts of member states is to be welcomed. It is a progressive step that should bring European countries closer together where the previously prevailing approach in England would be likely to drive them apart. The exception to this positive assessment of the paradigm-shift in European IPL is in respect of arbitration agreements, where the anti-suit injunction has been taken from the English courts without provision of an effective alternative under the Brussels I Regulation or the Recast. This author takes the view that this is a problem inherent in the Regulation's relationship, or lack thereof, with arbitration, best addressed when the instrument is next reviewed, and certainly not a problem that justifies regression to the archaic practice of restraint of proceedings before foreign courts. In short, this is an area in which tradition should not be allowed to stand in the way of progress.

jurisdiction and the recognition and enforcement of judgments in civil and commercial matters (Recast) COM (2010) 748 final, s 36.

${ }^{91}$ European Parliament Resolution of 7 September 2010 on the implementation and review of Council Regulation (EC) No 44/2001 on jurisdiction and recognition and enforcement of judgments in civil and commercial matters (2009/2140(INI)) [2010] OJ C 308 E/36, paras 5-8.

92 See the Council's Press Release on the Recast: Recast of the Brussels I Regulation: towards easier and faster circulation of judgments in civil and commercial matters within the EU 16599/12 PRESSE 483.

93 Brussels I Regulation Recast, above n 81, Recital 12.

${ }^{94}$ For a summary of the changes and a short comment, see Dowers \& Holloway, above n 84.

95 Ibid, N21.

96 Ibid. 